\title{
A third space: reconsidering issues of neutrality and accessibility in the virtual art museum
}

\author{
Theopisti Stylianou-Lambert \\ Cyprus University of Technology \\ 9 Diagorou Street, \\ K. Lakatameia, Nicosia 2334, Cyprus \\ theopisti.stylianou@cut.ac.cy
}

\author{
Elena Stylianou \\ European University Cyprus \\ Demetriou Karatasou, 5, Flat 101, \\ Strovolos, Nicosia 2024, Cyprus \\ e.stylianou@euc.ac.cy
}

\begin{abstract}
When the European Institute for Comparative Cultural Research called museums to create 'third spaces in which different groups can share a similar experience of discovery' (2008, p. 124), it was making the assumption that these spaces can be neutral, democratic, accessible, and thus universal. Such assumptions have been applied to the virtual as a third and seemingly neutral space that museums were found lacking. However, the fascination and preoccupation with the virtual, as the panacea to issues of democracy and accessibility, needs to be reconsidered and challenged. This article questions the neutrality of and degree of accessibility to the virtual space within the framework of Bourdieu's theories and by examining the processes of construction and use of virtual art museums.
\end{abstract}

Third space. Accessibility. Neutrality. Art museums. Virtual. Digital

\section{INTRODUCTION}

Recognising the potential of digital technologies, museum professionals and researchers have dedicated great amounts of time, expertise, and resources to develop and evaluate virtual museum websites that provide more than mere information about opening hours, directions, programs, and current or future exhibitions. Instead, virtual museums have recently been re-conceptualised as complementary rather than a substitute to actual museums and as spaces for exploration and interactivity that ultimately provide educational opportunities for all. For example, the Tate Online (http://www.tate.org.uk) was developed as a 'fifth gallery' which aims to increase access and understanding of the Tate's other four museums (Tate Britain, Tate Modern, Tate Liverpool and Tate St. Ives) along with expanding and diversifying audiences (Soren \& Lemelin, 2004). In addition, recognising the importance of online cultural presence many museums are designed to exist only virtually, without a physical counterpart. The Museum of the Person in Sao Paolo, Brazil is such an example (other examples are: Culture24, Eternal Egypt, Virtual Museum of Canada, Odysseus). It aims to give ordinary people the opportunity to record and present their personal narratives, fostering their active involvement in the formation of an online archive of public memory.
A museum's virtual presence online is more than a reflection of the museum's physical site and does not necessarily satisfy the same visitor needs and expectations. Acknowledging this, Marty (2008, p. 96) encouraged developers of museum websites to 'take advantage of the online environment to offer unique experiences that cannot be duplicated in physical museums, including customisation and personalisation technologies'. Interactive activities, interconnected information, games, podcasts, videos, 3D simulations, forums, and other possibilities offered by digital technologies are considered ways towards the creation of unique experiences. They are also thought of as a way to create a virtual social space that promotes moderated debate and discussion through visitor interaction and participation; a third space.

The European Institute for Comparative Cultural Research (2008, p. 124) called for museums to create such 'third spaces in which different groups can share a similar experience of discovery'. Technological advances and the online possibilities available suggest that online museums can become these 'third spaces' where users can experience and share a sense of discovery of other cultures as much as of their own. However, such an argument is based on the assumption that these virtual spaces are at least neutral and thus 
democratic and accessible, and at best universal. This article argues instead that such assumptions are naïve and need to be reconsidered and challenged. It will further provide the theoretical framework for a further examination of these issues, specifically in relation to Bourdieu's theories.

\section{CHALLENCING NEUTRALITY}

\subsection{Cultural authority}

According to Janes (2007, p. 139), 'museums are uniquely placed, among contemporary social institutions, in their potential to make the moral, social, and practical legacies of human society both visible and accessible - in a way that is free of any particular agenda'. Nevertheless, the neutrality of museums, as well as the way they accumulate, select, interpret, and represent artefacts considered worthy of preservation and exhibition, has been challenged over the years (Bennett, 2003, 2005; Duncan, 1993, 1997; Fleming, 2004). 'All museums are exercises in classification', argues Jordanova (2006, p. 23). When museum visitors look at an object exhibited, they not only learn about that specific something presented but also about the larger processes of constructing meaning and knowledge within a particular history of looking and specific mechanisms of display. Information provided by the museum, either in the form of labels or text panels, serves as a classificatory system that pertains to issues of authorship, authenticity, values, and originality. In other words "although labels offer a context within which the item in question can be "read", this context is limited, selective, and manipulative, since it generally invites visitors to perceive in a particular way' (Jordanova, 2006, p. 24). This is especially true in the case of art museums often characterised as elitist and exclusive in a process of defining what is art and what not.

Art museums are institutions that function within a larger and well established socio-cultural and political framework. They are part of a larger complex cultural system that has the sole power of labelling something as a work of art worthy of attention and study, following a long tradition of conventions and the art historical canon. Along the same lines, Dickie (1974, p. 464) defined a work of art in the following way:

A work of art in the classificatory sense is (1) an artefact (2) a set of the aspects of which has had conferred upon it the status of candidate for appreciation by some person or persons acting on behalf of a certain social institution (the artworld).
The artworld, a network of artists, art critics, curators, gallery owners, museum professionals, collectors and art historians and scholars, adjusts according to personal taste, biases and economic standards, the degree of a work's aesthetic and historical value (Becker, 1982; Danto, 1992; Dickie, 1974). Nevertheless, most people still consider museums, more than other media (such as television, magazines, and books), to be trustworthy and reliable, and to provide unbiased information (Sandell, 2007). Therefore, museums have been historically invested with the power to present certain points of view as natural, acceptable, and truthful.

This 'cultural authority' and perceived sincerity of museums which can endorse dominant social and cultural narratives is carried over in the virtual spaces online. Museum websites are also considered to be reliable sources of information. More specifically, due to museums' ownership of the Intellectual Property Rights to a large quantity of quality content, they have established a reputation for quality, authority, and objectivity (Cunliffe, Kritou \& Tudhope, 2001). However, as in the case of physical museums, issues of authorship and representation are also prevalent in virtual museums. Similarly, this type of authority unavoidably carries a burden of responsibility responsibility for the messages presented and for the messages not presented both in the physical and the virtual museum.

Since online museums mostly draw on museums' existing philosophies, collections, and practices, then the same questions concerning the selection and interpretation of objects presented become relevant: What is selected for exhibition and by whom? How is the object interpreted and why? What is omitted or assumed in the absence of sanctioned interpretations? Who is the assumed audience? What knowledge does a visitor need to bring with him/her in order to de-code a work of art? As a matter of fact these questions become more urgent in the case of virtual objects since they go through a dual selection process - the first process takes place when the object is considered worthy of preservation and exhibition at the physical museum and the second when it is chosen to be represented digitally in the museum's online collection. Furthermore, the process of digitisation of artworks complicates the process of signification or mediation by reducing the image, and as a consequence of its denoted message, into a series of ones and zeros. In this sense, digitisation introduces a final level of abstraction into the process of mediation of messages 'by imposing a finite scheme of encoding that translates all messages into one abstract universal code, the digital code; a code without an analogy to its origin.' (Kluitenberg, 2008, p. 332). This does not mean 
that the language of digital media is universal but rather that in this process of abstraction the mechanisms of signification remain unseen. They are 'deliberately hidden beneath the illusionary surface of the screen' (Kluitenberg, 2008, p. 333).

\subsection{Digital dominance}

Initial excitement with the interface has had its locus in the assertion that virtual worlds contained the possibility of a constructed utopian location that fulfilled the needs of the fragmented identity of the postmodern individual. The Net could be a nowhere (outopia) that is also some place good (eutopia) where the self can be an ever-changing fluid and polymorphous entity; a place that has no specific location, yet opening up for 'collective restoration' (Robins, 2000). Howard Rheingold, and other theorists, wishfully argued that the Net might ultimately recover the loss of America's sense of social commons, by building virtual communities that revitalise a democratic public sphere through 'communion and community' (Robins, 2000). However, a fascination with technological potential that remains uncritical leads to naïve fantasies of the Net as the panacea to (re)-current social and political issues of conflict, nationalism, racism etc. The virtual has never really existed in isolation and detached from the actual. Furthermore, as a human construction it is also similarly to the actual, charged with ideologies, biases and preestablished knowledge. For instance, the technological promise of a free, disembodied existence, removed from the physical and bodily particularities and often constrains, 'comes from a sense of transcendence and liberation from the material and embodied world' (Robins, 2000, p. 138) that has been at the core of being human. Michael Benedikt (1991, p. 6) specifically asserts that, '[c]yberspace can be seen as an extension, some might say an inevitable extension, of our ageold capacity and need to dwell in fiction, to dwell empowered on other, mythic planes'.

The romanticised understanding of the Web as a 'decentralised, open, transnational and translocal [space], a space in which all of the connected could represent themselves and their interest on an equal basis' is a sheer utopia (Kluitenberg, 2008, p. 290). What initially seemed to be a virtual manifestation of the ideal Platonic polis, in the interface of the Web, is currently reconsidered as a highly privatised and occupied space by very specific forces. For instance, in the case of heritage sites and museums, Morbey (2006) uses as a case study the State Hermitage Museum, St. Petersburg in Russia to argue that large development companies such as IBM tend to 'cybercolonise' a museum by using a particular form of website structuring and design, applying their e-business identity, and using US American English branding.
One could claim that technology can diffuse the power of the artworld and empower the visitor. There is a clear shift from being a receiver of information in the actual museum to being a sender of, or actor upon, information in the virtual one. Even though the space of the Web is widely available and in the public domain, viewing and interacting activities are distinctly private (Kluitenberg, 2008) and thus ensuring the empowerment of the viewer/visitor. In a sense, the success of digital environments lies in this exact possibility of fulfilling a desire of anonymity and privacy, without excluding enactment and participation. For example, some virtual museums online, such as the Metropolitan Museum of Art and the Minneapolis Institute of Arts, offer visitors the option to select their own artworks in order to create more personalised virtual galleries. However, the degree of freedom of such actions is debatable, because although visitors have the option to select from a database of hundreds or even thousands of objects, these objects come from a database created by a specific museum, or a group of museums, and thereby are already highly pre-selected by the artworld and for the visitor/viewer. The virtual is only an extension of the decisions taken by the artworld and is influenced by the same cultural, social, and political structures as its physical counterparts; on the basis of which any assumption of democracy in the virtual space is faulty.

\section{CHALLENCING ACCESSIBILITY}

\subsection{Decoding processes}

The notion of the museum as an institution open to everyone is considered by Bourdieu (1968, p. 611) a 'false generosity' since only those who have immediately and completely mastered the cultural codes of art have the possibility and therefore the privilege to use it. The difficulty of deciphering cultural codes lies in the difficulty of gaining access to the devices for their decoding, which are mainly education and upbringing in a cultured family (Miller, 1987). For instance, even though Barnett Newman claimed that 'for a work of art to be a work of art, it must rise above grammar and syntax' (as cited in Danto, 2005, p. 69), understanding that the twelfth panel of his The Stations of the Cross is actually The Death of Christ requires more than just a general sense of appreciation of the work as a work of art. Instead, the work cannot exist without its specific meanings, and these meanings cannot exist if the panel was to be shown isolated from the other panels, or if 'experienced by someone who does not know that these are Stations of the Cross, or does not know what the Stations of the Cross are' (Danto, 2005, p. 73). 
Danto (2005) is right when arguing that a work's identity is deeply defined by its cultural location and inevitably one's experiences with art are squared with ones' knowledge and understanding of that culture. Similarly, Bourdieu (1984) argued:

\begin{abstract}
The question of the conditions that make it possible to experience the work of art (and, in a more general way, all cultural objects) as at once endowed with meaning is totally excluded from the experience itself, because the recapturing of the work's objective meaning (which may have nothing to do with the author's intention) is completely adequate and immediately effected in the case - and only in the case - where the culture that the originator puts into the work is identical with the culture or, more accurately, the artistic competence which the beholder brings to the deciphering of the work.
\end{abstract}

Accessibility measured by the ease and sense of confidence with which a visitor views and interacts with visual information holds true both in the physical and in the virtual museum. The lack of 'trained eyes' makes the experience with art difficult, even uncomfortable, and the least educational.

\subsection{The online museum visitor}

Evidence exist that online museum visitors often exceed the numbers of physical visitors (Hawkey, 2002; Soren \& Lemelin, 2004) and not without a good reason. Online visitors have instant and immediate access to artworks and information 24 hours a day within a personal environment. Furthermore, as technology has improved, more museums have been instantly updating information and thus providing online visitors the latest knowledge about their collections. Even though we know that online visitors are increasing in number, we do not know much about who they are and whether or not they differ from in-person visitors.

The limited research available indicates that there are not great demographic differences between online and in-person visitors. For example, Thomas and Carey (2005) examined the two kinds of visitors to Canadian museums and found links between the two groups. Similarly, Sarraf (1999) found that the 'average' online museum visitor is female, close to middle age, educated, and fairly wealthy. Interestingly, this description fits the 'average' in-person museum visitor who is generally located within the upper educational, occupational, and income groups (Bourdieu \& Darbel, 1991; DiMaggio et al., 1977; Eurostat, 2007; Schuster, 1993). Furthermore, Marty (2007, 2008) found a strong connection between the frequency of the participants' actual museum visitation and their visitation of museum websites. In other words, it is possible that the same people who visit museums also visit museum websites. This raises questions concerning the degree of accessibility of online museums. If online museums attract the same kind of audiences as physical museums, then how could one possibly claim that online museums are more accessible? Furthermore, research findings show that online visitors mainly look for general information on a museum's website, despite the website's available interactive possibilities such as web-based activities, forums, etc. (Thomas \& Carey, 2005). This raises additional questions concerning the actual use of the virtual third space. What is supposedly a space tailored to increase participation, inclusiveness, and audience activity seems to be failing to fulfil its potential.

\subsection{Technology}

Considering perception to be the articulation of one's orientation within a socio-cultural framework, then similarly the engagement with the interface will be well defined and informed by that exact framework. Nowadays, the interface is simply another spatio-temporal organisation, the awareness of which is the result of the contingency of human experience, 'situated both within the moment of perception and also within world-views mediated by and mediating interplays of political, social, cultural and economic discourse' (Wood, 2007, p. 163). When examining people's engagement with a virtual museum online, it is of importance to question not only the experience with the works of art presented but with the interface itself. The virtual space is an architectural structure similar to the architecture of the actual museum that among other elements influences the degree and quality of a visitor's access.

The design and structure of a virtual museum site are barely neutral (Morbey, 2000). Access to development and design expertise can play a role in how a museum and its artefacts are presented. Beyond certain common issues of access, such as the lack of technology or of the Internet in remote geographic areas or among low-income families and non-English speakers, the largest virtual museums online are based in the UK, USA, Canada, and Australia. Here large amounts of monetary and staff resources are spent on the development, promotion, and evaluation of online museums, often with little alternative for nonEnglish speaking visitors. Despite the increasing number of virtual museums that seemingly expand one's cultural and artistic competence through increasing familiarisation with works of art online, there are still questions to be asked concerning 'who controls and creates those interfaces and for what reasons' (Wood, 2007, p. 163). 


\section{CONCLUSION}

Bourdieu \& Darbel (1991) claimed that the seemingly open-for-all art museum simply gives the illusion of a democratic space, whereas in actuality is limiting, predetermined, and geared toward the few highly educated visitors. This argument could also apply to virtual museums online. Any arguments of neutrality and of a higher degree of accessibility in the virtual fall short fulfilling technology's potential of creating a third and more democratic space for museum audiences. Because, beyond issues concerning the limitations of digital technologies in application, the specific characteristics of online museums are squared with similar issues of cultural authority, politics of display, and taxonomies of knowledge and meaning, as their physical counterparts. The virtual is not by definition and a priori democratic, but instead, similarly to any other human construct, well embedded in social and cultural practices, thus often defining and perpetuating the structures that was originally expected to challenge. This is not to argue against the creation and sustaining of such 'third spaces', but rather to critically reconsider their design, use and function. The consequences of better understanding their degree of failure and success of neutrality and accessibility are twofold: a) that virtual museums online still have some way to go before they are more than mere replicas of the physical art museum and b) that for the virtual to actually become this much needed third space that will respond to the needs of wider museum audiences, it needs to be framed within reconsidered theories of democracy in the postmodern vernacular.

\section{REFERENCES}

Becker, H. S. (1982) Art Worlds. University of California Press, Berkeley, London.

Benedikt, M. (1991) Introduction. In M. Benedikt, M. (ed.) Cyberspace: First Steps, pp. 1-25. MIT Press, Cambridge.

Bennett, T. (2003) The Political Rationality of the Museum. In Lewis, J. \& T. Miller (Eds.) Critical Cultural Policy Studies Reader (pp. 180-187). Blackwell Publishings, Malden, Oxford, Victoria, Berlin.

Bennett, T. (2005) The Birth of the Museum: history, theory, politics. Routledge, London and New York.

Bourdieu, P. (1968) Outline of a Sociological Theory of Art Perception. International Social Science Journal, 20 (4), pp. 589-612.
Bourdieu, P. (1984) The Field of Cultural

Production: Essays on Art and Literature. Columbia University Press, New York.

Bourdieu, P. and Darbel A. (1991) The Love of Art: European Art Museums and their Public. Polity Press, Cambridge.

Cunliffe, D., Kritou, E., and Tudhope, D. (2001) Usability Evaluation for Museum Web Sites. Museum Management and Curatorship, 19(3), pp. 229-252.

Danto, A. (1992) Beyond the Brillo Box: the visual arts in post-historical perspective. University of California Press, Berkeley, London.

Danto, A. (2005) The Philosophical Disenfranchisement of Art. Columbia University Press, New York.

Dickie, G. (1974) Art and the Aesthetic. Cornell University Press, Ithaca.

DiMaggio, P., Useem, M. and Brown P. (1977) Audience studies in the performing arts and museums: A critical review. National Endowment for the Arts, Washington.

Duncan, C. (1993) The Aesthetics of Power: Essays in Critical Art History. Cambridge University Press, Cambridge and New York.

Duncan, C. (1997) Civilizing Rituals: inside public art museums. Routledge, London and New York.

European Institute for Comparative Cultural Research (2008, March). Sharing Diversity: National Approaches to Intercultural Dialogue in Europe, Study of the European Commission. European Institute for Comparative Cultural Research, Bonn.

Eurostat (2007) Eurostat Pocketbook: Cultural Statistics. European Commission.

Fleming, D. (2004) Positioning the museum for social inclusion. In R. Sandell (ed.) Museums, Society, Inequality. pp. 213-224. Routledge, London and New York.

Hawkey, R. (2002) The lifelong learning game: season ticket or free transfer? Computers \& Education, 38(1/3), pp. 5-20.

Janes, J. R. (2007) Museums, Social Responsibility and the Future we Desire. In S. Knell, S. MacLead, and S. Watson (eds.) Museum Revolutions: How museums change and are changed. pp.134-146. Routledge, Oxon.

Jordanova, L. (2006) Objects of Knowledge: A Historical Perspective on Museums. In P. Vergo 
(ed.) The New Museology. pp. 22-40. Reaktion Books Ltd, London.

Kluitenberg, E. (2008) Delusive Spaces: Essays on Culture, Media and Technology. NAi Publishers, Institute of Network Cultures, Rotterdam.

Marty, P. F. (2007) Museum Websites and Museum Visitors: Before and After the Museum Visit. Museum Management and Curatorship, 22(4), pp. 337-360.

Marty, P. F. (2008) Museum websites and museum visitors: digital museum resources and their use. Museum Management and Curatorship, 23(1), pp. 81-99.

Miller, D. (1987) Material Culture and Mass Consumption. Basil Blackwell, Oxford, New York.

Morbey, M. L. (2000) Academic computing and beyond: New opportunities for women, minority populations, and the new media arts. Convergence: The Journal of Research into New Media Technologies, 6(4), pp. 54-77.

Morbey, M. L. (2006) Killing a culture softly: Corporate partnership with a Russian museum. Museum Management and Curatorship, 21(4), pp. 267-282.
Robins, K. (2000) Cyberspace and the world we live in. In M. Featherstone, \& R. Burrows (eds.) Cyberspace, Cyberbodies, Cyberpunk: Cultures of Technological Embodiment, pp. 135 -155. Sage Publications, London.

Saffar, S. (1999) A Survey of Museums on the Web: Who Uses Museum Websites? Curator, 42(3), pp. 231-243.

Sandell, R. (2007) Museums, Prejudice and the Reframing of Difference. Roudledge, London and New York.

Schuster, M. D. J. (1993) The Audience for Museums: A Cross-national Comparison. MIT Press, Cambridge.

Soren, B. J. and Lemelin, N. (2004) 'Cyperpals!/Les Cybercopains!': A look at Online Museum Visitor Experiences. Curator, 47(1), pp. 55-83.

Thomas, W. and Carey, S. (2005) Actual/Virtual Visits: What are the links? In J. Trant and D. Bearman (eds.). Museums and the web 2005: Proceedings, Toronto: Archives \& Museum Informatics, published March 31, 2005 at http://www.archimuse.com/mw2005/papers/thomas /thomas.html

Wood, A. (2007) Digital Encounters. Routledge, London and New York. 